\title{
PENGARUH RASIO KEUANGAN DAN PERTUMBUHAN LABA TERHADAP KEBIJAKAN DIVIDEN PADA PERUSAHAAN MANUFAKTUR DI BEI
}

\author{
Sinta Cahyanti \\ Fakultas Ekonomi, Universitas islam Lamongan \\ sintacahyanti4@gmail.com
}

\begin{abstract}
ABSTRAK
Kebijakan dividen adalah kebijakan yang dimiliki perusahaan untuk membagikan labanya kepada para pemegang saham, yaitu untuk memenuhi harapan para pemegang saham terhadap dividen dan di sisi lain juga tidak harus menghambat pertumbuhan perusahaan. Penelitian ini bertujuan untuk menguji pengaruh profitabilitas, likuiditas dan pertumbuhan laba terhadap kebijakan dividen. Adapun populasi yang digunakan adalah perusahaan manufaktur yang terdaftar di Bursa Efek Indonesia pada periode 2012 - 2016. Metode pengambilan sampel dilakukan dengan menggunakan purposive sampling, dan hasil pengambilan sampel dalam penelitian ini diperoleh 28 perusahaan. Teknik analisis datanya menggunakan regresi linier berganda. Hasil analisisnya menyebutkan bahwa profitabilitas berpengaruh positif dan signifikan terhadap kebijakan dividen, likuiditas negatif dan berpengaruh signifikan terhadap kebijakan dividen, pertumbuhan laba berpengaruh negatif dan signifikan terhadap kebijakan dividen dan leverage berpengaruh negatif dan signifikan terhadap kebijakan dividen.
\end{abstract}

Kata kunci : profitabilitas, likuiditas, pertumbuhan laba, leverage, Kebijakan Dividen.

\section{PENDAHULUAN}

Perkembangan Bursa Efek
Indonesia saat ini tidak dapat
dipisahkan dari peran investor yang
melakukan transaksi di BEI. Tujuan
utama investor menginvestasikan
dananya adalah untuk mencari
pendapatan atau tingkat kembalian
investasi baik berupa pendapatan
dividen maupun capital gain.
Kebijakan dividen merupakan
kebijakan dalam menentukan

besarnya laba perusahaan yang akan dibagikan sebagai dividen atau ditahan sebagai laba ditahan. Para investor umumnya menginginkan pembagian dividen yang relatif stabil, karena dengan stabilitas dividen dapat meningkatkan kepercayaan investor terhadap perusahaan sehingga mengurangi ketidakpastian investor dalam menanamkan dananya kedalam perusahaan (Nufiati dan Suwitho, 
2015). Semakin tinggi dividen yang dibagikan, berarti semakin sedikit laba ditahan, dan akibatnya dapat menghambat tingkat pertumbuhan laba dan harga saham. Sebaliknya, apabila perusahaan berkeinginan untuk menahan laba di tangan, maka kepentingan para pemegang saham akan uang kas juga menjadi terabaikan.

Rasio profitabilitas sangat bermanfaat bagi kelangsungan perusahaan karena dapat membantu perusahaan untuk mengetahui kontribusi keuntungan perusahaan dalam jangka pendek atau jangka panjang. Oleh karena itu dividen diambil dari keuntungan bersih yang diperoleh perusahaan, maka keuntungan tersebut akan mempengaruhi besarnya dividend payout ratio. Semakin besar keuntungan yang diperoleh, maka akan semakin besar pula kemampuan perusahaan untuk membayar dividen.

Likuiditas merupakan rasio yang menggambarkan kemampuan perusahaan dalam memenuhi kewajiban jangka pendek (Sudana, 2015:24). Posisi likuiditas perusahaan pada kemampuannya pembayaran dividen sangat berpengaruh karena dividen dibayarkan dengan kas dan tidak dengan laba ditahan, perusahaan harus memiliki kas tersedia untuk pembayaran dividen. Sehingga tinggi rendahnya likuiditas perusahaan dapat mempengaruhi kebijakan dividen suatu perusahaan.

Leverage digunakan untuk melihat kemampuan perusahaan dalam memenuhi segala kewajiban finansialnya apabila perusahaan dilikuidasi (Hanafi, 2013:37). Rasio ini memfokuskan pada kewajiban perusahaan, jika rasio tinggi berarti menggambarkan gejala yang kurang baik bagi perusahaan, peninggakatan hutang akan mempengaruhi besar kecilnya laba bersih yang tersedia atau diterima bagi para pemegang saham.

Dalam pembagian dividen pertumbuhan laba juga menjadi pertimbangan dalam menentukan kebijakan dividen karena pertumbuhan laba merupakan tingkat perubahan total laba dari tahun ke tahun. Para Investor cenderung memusatkan perhatian pada angka laba yang tertera di dalam laporan keuangan guna 
$\begin{array}{lr}\text { memprediksi } & \text { besarnya } \\ \text { pengembalian atas investasinya } \\ \text { dimasa depan. }\end{array}$

Berdasarkan pada latar belakang yang diuraikan diatas, maka rumusan masalah dalam penelitian ini adalah apakah profitabilitas, likuiditas dan pertumbuhan laba berpengaruh terhadap kebijakan dividen pada perusahaan manufaktur yang terdaftar di BEI. Tujuan dari dilakukannya penelitian ini adalah untuk mengetahui dan menganalisis pengaruh rasio keuangan dan pertumbuhan laba terhadap kebijakan dividen.

\section{METODE PENELITIAN}

Jenis penelitian yang dilakukan dalam penelitian ini adalah penelitian kuantitatif karena analisisnya secara umum menggunakan data yang diukur dalm skala numeric (angka) yang dapat diuji menggunakan analisis statistik, sedangkan berdasarkan karakteristik masalah yang diteliti, penelitian ini termasuk penelitian kausal komparatif. Penelitian kausal komparatif adalah penelitian yang menunjukkan arah hubungan antara variabel bebas dengan variabel terikat, di samping mengukur kekuatan hubungannya. Penelitian bertujuan untuk mengetahui pengaruh variabel independen (profitabilitas, likuiditas dan pertumbuhan laba) terhadap variabel dependen (dividend payout ratio).

Populasi dalam penelitian ini adalah seluruh perusahaan manufaktur yang terdaftar di Bursa Efek Indonesia. Pengambilan sampel dalam penelitian dilakukan dengan metode purposive sampling artinya bahwa populasi yang dijadikan sampel dalam penelitian ini adalah populasi yang memenuhi kriteria sampel yang dikehendaki peneliti sesuai dengan pertimbangan. Adapun proses pengambilan sampelnya adalah sebagai berikut :

Tabel 1. Proses Pengambilan Sampel

\begin{tabular}{|l|c|}
\hline Keterangan & Jumlah \\
\hline $\begin{array}{l}\text { Perusahaan manufaktur } \\
\text { yang terdaftar di Bursa Efek }\end{array}$ & 128 \\
$\begin{array}{l}\text { Indonesia selama periode } \\
\text { pengamatan (2012-2016) }\end{array}$ & \\
\hline $\begin{array}{l}\text { Perusahaan yang tidak } \\
\text { melaporkan laporan }\end{array}$ & $(23)$ \\
keuangannya dalam mata & \\
uang rupiah. & \\
\hline $\begin{array}{l}\text { Perusahaan yang } \\
\text { mengalami kerugian selama } \\
\text { periode pengamatan (2012- } \\
\text { 2016). }\end{array}$ & \\
\hline
\end{tabular}




\begin{tabular}{|l|c|}
\hline $\begin{array}{l}\text { Perusahaan yang tidak } \\
\text { membagikan dividen. }\end{array}$ & $(35)$ \\
\hline $\begin{array}{l}\text { Perusahaan yang tidak } \\
\text { memiliki data lengkap } \\
\text { berupa laporan keuangan } \\
\text { selama periode pengamatan } \\
(2012-2016)\end{array}$ & $(10)$ \\
\hline $\begin{array}{l}\text { Jumlah Perusahaan yang } \\
\text { menjadi sampel }\end{array}$ & $\mathbf{2 8}$ \\
\hline
\end{tabular}

Teknik pengumpulan data yang digunakan dalam penelitian ini adalah dokumentasi yaitu data yang diperoleh dari dokumen/catatan pihak lain. Dalam penelitian ini data yang digunakan adalah laporan keuangan perusahaan manufaktur yang terdaftar di BEI Tahun 20122016 yang dipublikasikan oleh perusahaan melalui website resmi dan Bursa Efek Indonesia.

\subsection{Variabel dan Definisi}

\section{Operasional variabel}

\section{A. Variabel Dependen (Y)}

Dalam penelitian ini variabel dependen yang digunakan yaitu kebijakan dividen. Kebijakan Dividen (Dividend Payout Ratio) merupakan sebagian dari laba bersih perusahaan yang dibagikan kepada para pemegang saham. Dividend Payout Ratio dapat dirumuskan sebagai berikut :

$$
D P R=\frac{\text { Dividen Persaham }}{\text { Laba Persaham }}
$$

Sumber : Murhadi (2015:65)

\subsection{Variabel Independen}

Variabel independen yang digunakan peneliti yaitu:

1. Profitabilitas $\left(\mathrm{X}_{1}\right)$

Rasio profitabilitas digunakan untuk mengukur efektivitas manajemen secara keseluruhan yang ditujukan oleh besar kecilnya tingkat keuntungan yang diperoleh dalam hubungannya dengan penjualan maupun investasi (Fahmi, 2014:164). Rasio yang digunakan dalam penelitian ini adalah Return On Asset (ROA)

$$
R O A=\frac{E A T}{\text { Total Assets }}
$$

Sumber : Fahmi (2014 : 165)

\section{Likuiditas $\left(\mathrm{X}_{2}\right)$}

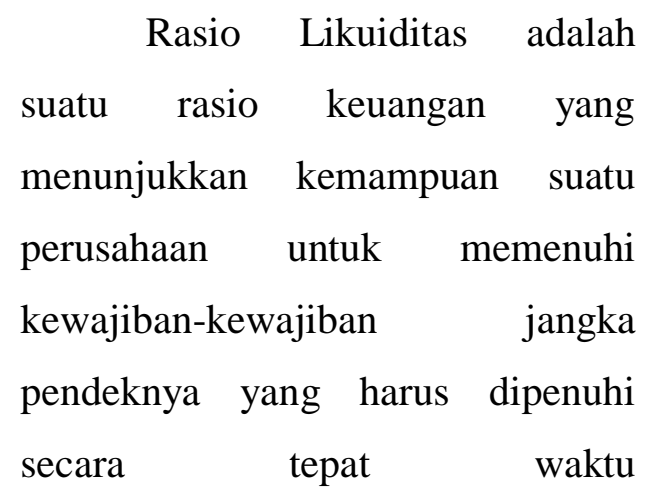
(Fahmi,2014:153). Rasio ini diukur dengan melihat current ratio. 


$$
\text { Current Ratio }(C R)=\frac{\text { Aktiva lancar }}{\text { Pasiva lancar }}
$$

Sumber : Tampubolon (2013 : 41)

3. Pertumbuhan Laba $\left(X_{3}\right)$

Laba merupakan selisih pendapatan dan keuntungan setelah dikurangi beban dan kerugian. pertumbuhan laba merupakan tingkat perubahan total laba dari tahun ke tahun.

$P L=\frac{\text { Laba bersih tahun } t-l a b a \text { bersih } \operatorname{tahun} t-1}{\text { Laba bersih tahun } t-1}$

Sumber : Rachmawati (2014)

4. Leverage $\left(\mathrm{X}_{4}\right)$

Rasio Leverage digunakan untuk melihat kemampuan perusahaan dalam memenuhi segala kewajiban finansialnya apabila perusahaan dilikuidasi.
Rasio yang digunakan dalam penelitian ini adalah debt to equity ratio.

$$
D E R=\frac{\text { TotalHutang }}{\text { Total Aktiva }}
$$

Sumber : Harjito dan martono (2014:59)

\subsection{Metode Analisis Data}

Metode analisis data yang digunakan dalam penelitian ini adalah metode analisis statistik. Untuk mengetahui pengaruh dari masing masing variabel yang diteliti terhadap kebijakan dividen, penelitian ini menggunakan analisis regresi linier berganda dengan terlebih dahulu melakukan pengujian asumsi klasik.

\section{ANALISIS DAN PEMBAHASAN}

Tabel 2. Descriptive Statistics

\begin{tabular}{cccccc}
\hline & $\mathrm{N}$ & Min & Max & Mean & $\begin{array}{c}\text { Std. } \\
\text { Deviation }\end{array}$ \\
\hline ROA & 140 & 0,0145 & 0,4150 & 0,132935 & 0,0882506 \\
CR & 140 & 0,6056 & 9,3446 & 2,668856 & 1,5956315 \\
PL & 140 & $-0,7373$ & 3,1405 & 0,118395 & 0,5561651 \\
DER & 140 & 0,0100 & 6,8900 & 0,768071 & 0,8098165 \\
DPR & 140 & 0,0644 & 2,0227 & 0,456079 & 0,3137310
\end{tabular}

Sumber:Hasil output SPSS 
Dari Tabel 2, diketahui bahwa jumlah pengamatan $(\mathrm{N})$ pada perusahaan manufaktur yang terdaftar di Bursa Efek Indonesia periode 2012 - 2016 adalah sebanyak 140 data. Variabel Return On Assets menunjukkan nilai minimum yaitu sebesar 0,0145 yang terjadi pada perusahaan Lionmesh Prima Tbk (LMSH) pada tahun 2015 yang diakibatkan oleh laba bersih pada perusahaan tersebut mengalami penurunan yang signifikan dari tahun sebelumnya, nilai maksimum diketahui sebesar 0,4150 pada perusahaan Unilever Indonesia Tbk (UNVR) pada tahun 2014 karena pada periode tersebut laba bersih dan total aset mengalami kenaikan. Nilai mean menunjukan 0,132935 Hal ini berarti bahwa ratarata perusahaan sampel mampu mendapatkan laba bersih sebesar $13 \%$ dari total asset yang dimiliki perusahaan dalam satu periode dan nilai standart deviasi sebesar 0,0882506 .

Variabel Current Ratio menunjukan nilai terendah (minumum) adalah 0,6056 terjadi pada perusahaan Unilever Indonesia Tbk (UNVR) pada tahun 2016 karena pada periode tersebut mengalami peningkatan kewajiban jangka pendek pada perusahaan, nilai tertinggi (maximum) sebesar 9,3446 terjadi pada perusahaan Lion Metal Works Tbk (LION) pada tahun 2012 diakibatkan oleh aset lancar dan kewajiban jangka pendek pada periode tersebut relatif sedikit dibandingkan tahun sesudahnya. Variabel Current Ratio memiliki nilai rata - rata (mean) sebesar 2,668856 Hal ini berarti rata-rata perusahaan sampel mampu memenuhi kewajiban jangka pendeknya sebesar $27 \%$ dari aset lancar yang dimiliki perusahaan dalam satu periode dan nilai standart deviasi sebesar 1,5956315.

Variabel Pertumbuhan Laba menunjukkan nilai terendah (minumum) adalah $-0,7373$ terjadi pada perusahaan Lionmesh Prima Tbk (LMSH) pada tahun 2015 karena pada periode ini perusahaan mendapatkan laba yang sedikit dibandingkan tahun sebelumnya, nilai tertinggi (maximum) sebesar 3,1405 pada perusahaan Japfa Comfeed Indonesia Tbk (JPFA) tahun 2016 karena pada tahun tersebut perusahaan mengalami 
peningkatan laba yang cukup signifikan. Variabel Pertumbuhan Laba memiliki nilai rata - rata (mean) sebesar 0,118395 dengan nilai standart deviasi sebesar 0,5561651 .

Nilai terendah (minimum) pada variabel debt to equity ratio adalah 0,0100 pada perusahaan ASII tahun 2015 karena total hutang pada tahun tersebut relatif sedikit dan nilai maksimum yaitu 6,8900 pada perusahaan KLBF tahun 2013 karena total hutang mengalami kenaikan dan aktiva perusahaan relatif rendah, variabel debt to equity ratio memiliki nilai rata-rata atau mean sebesar 0,768071 dan standart deviation sebesar 0,8098165 .

Nilai terendah pada variabel dependen Kebijakan Dividen Dividend Payout Ratio (minimum) adalah 0,0644 terjadi pada perusahaan Sepatu Bata Tbk (BATA) tahun 2015 karena laba per saham mengalami kenaikan akan tetapi dividen per saham perusahaan relatif kecil pada tahun tersebut dan nilai tertinggi (maximum) sebesar 2,0227 pada perusahaan Hanjaya Mandala Sampoerna Tbk (HMSP) pada tahun 2016 dikarenakan dividen per saham pada tahun tersebut lebih besar dari pada laba per sahamnya. Variabel Kebijakan Dividen memiliki nilai rata - rata (mean) sebesar 0,456079 Hal ini berarti bahwa rata-rata kebijakan pembagian dividen adalah sebesar $46 \%$ dari laba per lembar saham yang diperoleh perusahaan. dengan nilai standar deviasi sebesar 0,3137310 .

\subsection{Uji Asumsi Klasik}

\section{A. Uji Normalitas}

Uji normalitas digunakan untuk mengetahui apakah suatu data mengikuti sebaran normal atau tidak. Uji ini menggunakan uji kolmogorov-smirnov dapat dikatakan normal jika nilai signifikansinya lebih besar dari 0,05 (5\%). Dari hasil pengujian dapat dilihat pada Tabel berikut ini :

Tabel 3. Hasil Uji Normalitas One-Sample Kolmogorov-Smirnov Test

\begin{tabular}{llr}
\multicolumn{2}{c}{ One-Sample Kolmogorov-Smirnov Test } \\
\hline N & Mean & $\begin{array}{c}\text { Unstandardize } \\
\text { d Residual }\end{array}$ \\
\hline Normal Parameters & St,b & 140 \\
& Std. & 0 E-7 \\
& Deviation & 0,58245856 \\
Most Extreme & Absolute & 0,076 \\
Differences & Positive & 0,053 \\
& Negative & $-0,076$ \\
Kolmogorov-Smimov Z & 0,895 \\
Asymp. Sig. (2-tailed) & & 0,400 \\
\hline
\end{tabular}

Sumber : Hasil output SPSS 
Berdasarkan output pengujian tersebut terlihat pada nilai Sig. (2tailed) menunjukkan sebesar 0,400 sehingga $0,400>0,05$. Hal ini berarti nilai residual terstandarisasi dinyatakan menyebar secara normal.

\section{B. Uji Heteroskedastisitas}

Uji Heteroskedastisitas bertujuan untuk mengamati ada tidaknya perubahan varian dari residual satu pengamatan ke pengamatan yang lain. Untuk mengetahui ada tidaknya gejala heteroskedastisitas antar variabel independen Pengujian dilakukan dengan uji Glejser yaitu meregresi setiap variabel independen dengan absolute residual sebagai variabel dependen.

Tabel 4. Hasil Uji Heteroskedastisitas

\begin{tabular}{|c|c|c|c|c|c|}
\hline \multirow[t]{2}{*}{ Model } & \multicolumn{2}{|c|}{$\begin{array}{l}\text { Unstandardized } \\
\text { Coefficients }\end{array}$} & \multirow{2}{*}{$\begin{array}{c}\begin{array}{c}\text { Standard } \\
\text { ized } \\
\text { Coeffici } \\
\text { ents }\end{array} \\
\text { Beta }\end{array}$} & \multirow[t]{2}{*}{$\mathrm{t}$} & \multirow[t]{2}{*}{ Sig. } \\
\hline & $\mathrm{B}$ & Std. Error & & & \\
\hline (Constant) & 0,266 & 0,126 & & 2,111 & 0,037 \\
\hline ROA & $-0,055$ & 0,049 & $-0,097$ & $-1,114$ & 0,267 \\
\hline $1 \mathrm{CR}$ & 0,096 & 0,057 & 0,147 & 1,694 & 0,093 \\
\hline PL & 0,025 & 0,057 & 0,037 & 0,429 & 0,668 \\
\hline DER & 0,022 & 0,034 & 0,056 & 0,645 & 0,520 \\
\hline
\end{tabular}

Sumber : Hasil output SPSS

Berdasarkan hasil uji Glejser yang telah dilakukan dapat disimpulkan bahwa semua nilai signifikansi dari setiap variabel independen di atas tingkat kepercayaan 0,05 . Oleh kavedde $1^{1 \mathrm{tu}} \mathrm{R}_{\mathrm{R}}$ model regresi tidak mengandung gejala heteroskedastisitas.

1

0,548

\section{Sumbe}

\section{Uji Autokorelasi}

Uji autokorelasi dilakukan untuk mengetahui korelasi antara anggota serangkaian data observasi. Untuk mengetahui adanya gejala autokorelasi digunakan uji Durbin Watson. Hasil analisis uji autokorelasi dapat dilihat pada Tabel berikut :

Tabel 5. Hasil Uji Autokorelasi 
sampai 2, maka dapat disimpulkan bahwa tidak terjadi autokorelasi antar residual.

\section{Uji Multikolinearitas}

Uji multikolinearitas digunakan untuk mengetahui dimana terdapat korelasi antara variabel-variabel independen. Gejala ini dapat diketahui dengan menggunakan perhitungan Tolerance dan Variance Inflation Factor (VIF). Jika nilai Tolerance berada di atas 0,10 dan VIF tidak boleh lebih dari 10, maka model dinyatakan tidak terdapat gejala multikolinier. Berdasarkan hasil penelitian pengujian multikolinieritas dapat dilihat pada Tabel berikut ini :

Tabel 6. Hasil Uji Multikolinieritas

\begin{tabular}{|c|c|c|c|}
\hline & \multirow{2}{*}{ Model } & \multicolumn{2}{|c|}{ Collinearity Statistics } \\
\hline & & Tolerance & VIF \\
\hline \multirow{4}{*}{1} & (Consta & & \\
\hline & $\mathrm{ROA}$ & 0,952 & 1,050 \\
\hline & CR & 0,949 & 1,054 \\
\hline & PL & 0,949 & 1,054 \\
\hline
\end{tabular}

\begin{tabular}{ccc}
\hline \multirow{2}{*}{ Model } & \multicolumn{2}{l}{ Collinearity Statistics } \\
\cline { 2 - 3 } & Tolerance & VIF \\
\hline DER & 0,946 & 1,057 \\
\hline
\end{tabular}

Sumber : Hasil output SPSS

Hasil pengujian tersebut menunjukkan bahwa variabel independen memiliki nilai tolerance $>0,10$ dan nilai $V I F<10$. Dengan demikian model regresi dalam penelitian ini terbukti terbebas dari gejala multikolonieritas.

\subsection{Analisis Regresi Linier Berganda}

Penelitian ini menggunakan regresi linier berganda dengan tujuan untuk menjelaskan hubungan antara perubahan respon (variabel dependen) dengan beberapa variabel independen yang mempengaruhi, atau untuk mengetahui prediksi nilai suatu variabel dependen dengan variabel independen yang lebih dari satu, yaitu profitabilitas, likuiditas, pertumbuhan laba terhadap kebijakan dividen, hasil pengolahan data sebagai berikut : 
Tabel 7. Hasil Uji Regresi Linier Berganda

\begin{tabular}{|c|c|c|c|c|c|c|}
\hline & \multirow[t]{2}{*}{ Model } & \multicolumn{2}{|c|}{$\begin{array}{c}\text { Unstandardized } \\
\text { Coefficients }\end{array}$} & \multirow{2}{*}{$\begin{array}{c}\text { Standardized } \\
\text { Coefficients } \\
\text { Beta }\end{array}$} & \multirow[t]{2}{*}{$\mathrm{t}$} & \multirow[t]{2}{*}{ Sig. } \\
\hline & & B & Std. Error & & & \\
\hline \multirow{5}{*}{1} & (Constant) & 0,228 & 0,207 & & 1,104 & 0,272 \\
\hline & ROA & 0,452 & 0,080 & 0,417 & 5,646 & 0,000 \\
\hline & $\mathrm{CR}$ & $-0,262$ & 0,093 & $-0,208$ & $-2,820$ & 0,006 \\
\hline & PL & $-0,495$ & 0,094 & $-0,390$ & $-5,275$ & 0,000 \\
\hline & DER & $-0,297$ & 0,097 & $-0,291$ & $-2,224$ & 0,023 \\
\hline
\end{tabular}

Sumber : Hasil output SPSS

Dari Tabel di atas menunjukkan persamaan regresinya sebagai berikut:

$\hat{\mathrm{Y}}=0,228+0,452 \mathrm{ROA}-0,262 \mathrm{CR}$ -

$0,495 \mathrm{PL}-0,297 \mathrm{DER}+\mathrm{e}$

Dari persamaan regresi di atas dapat dijelaskan :

a. Konstanta (a) sebesar 0,228. Hasil tersebut menyatakan bahwa jika tidak ada variabel Return On Assets, Current Ratio dan Pertumbuhan Laba maka kebijakan dividen (Y) adalah sebesar 0,228 .

b. Koefisien Return On Assets $\left(\mathrm{X}_{1}\right)$ sebesar 0,452. Hasil tersebut menunjukkan bila $R O A$ naik sebesar 1 poin maka akan menyebabkan peningkatan kebijakan dividen sebesar 0,452, dengan catatan variabel lain dianggap konstan.

c. Koefisien Current Ratio ( $\left.\mathrm{X}_{2}\right)$ sebesar -0,262. Nilai koefisien regresi negatif, hasil tersebut menunjukkan bila $C R$ naik sebesar 1 poin maka akan menyebabkan penurunan kebijakan dividen sebesar 0,262, dengan catatan variabel lain dianggap konstan.

d. Koefisien Pertumbuhan Laba $\left(X_{3}\right) \quad$ sebesar $\quad-0,495$. Nilai koefisien regresi negatif, hasil tersebut menunjukkan bila PL naik sebesar 1 poin maka akan menyebabkan penurunan kebijakan dividen sebesar 0,495, dengan catatan variabel lain dianggap konstan.

e. Koefisien Debt to Equity Ratio $\left(X_{4}\right) \quad$ sebesar $\quad-0,297 \quad$ Nilai koefisien regresi negatif, hasil tersebut menunjukkan bila DER naik sebesar 1 poin maka akan menyebabkan penurunan kebijakan dividen sebesar 0,297, dengan catatan variabel lain dianggap konstan. 


\section{A. Uji T}

Uji $t$ bertujuan untuk menguji masing-masing variabel independen (ROA,CR,PL) secara individu apakah mempunyai pengaruh terhadap variabel dependen (Kebijakan Dividen) dengan melihat tingkat signifikansinya $<5 \%$ adapun kriteria untuk pengujian hipotesis secara parsial, yaitu :

a. Jika $t_{\text {hitung }}>t_{\text {tabel }}$ atau $t_{\text {hitung }}<-$ $\mathrm{t}_{\text {tabel }}$, maka $\mathrm{H}_{0}$ ditolak dan $\mathrm{H}_{1}$ diterima

b. Jika $-\mathrm{t}_{\text {tabel }} \leq \mathrm{t}_{\text {hitung }} \leq \mathrm{t}_{\text {tabel }}$, maka $\mathrm{H}_{0}$ diterima dan $\mathrm{H}_{1}$ ditolak

\section{Pada Tabel regresi} menunjukkan nilai ROA memiliki signifikansi penelitian sebesar 0,000 $<0,05$ maka $\mathrm{H}_{0}$ ditolak dan $\mathrm{H}_{1}$ diterima, artinya Profitabilitas yang diukur dengan Return On Assets secara parsial berpengaruh signifikan terhadap Kebijakan Dividen.

Nilai signifikansi Curent Ratio sebesar 0,006 $<0,05$ maka $\mathrm{H}_{0}$ ditolak dan $\mathrm{H}_{1}$ diterima, artinya Likuiditas yang diukur dengan Curren Ratio secara parsial berpengaruh signifikan terhadap Kebijakan Dividen.

Nilai signifikansi untuk pertumbuhan laba sebesar $0,000<$ 0,05, maka $\mathrm{H}_{0}$ ditolak dan $\mathrm{H}_{1}$ diterima, artinya pertumbuhan laba secara parsial berpengaruh signifikan terhadap kebijakan dividen.

Sedangkan nilai signifikansi untuk debt to equity ratio sebesar $0,023<0,05$ maka $\mathrm{H}_{0}$ ditolak dan $\mathrm{H}_{1}$ diterima, artinya debt to equity ratio secara parsial berpengaruh signifikan terhadap kebijakan dividen.

\section{B. Uji F}

Uji $F$ bertujuan untuk melihat pengaruh secara simultan atau bersama - sama ROA, CR dan Pertumbuhan Laba terhadap Kebijakan Dividen. Uji ini dilakukan dengan ketentuan sebagai berikut :

a. Jika $\mathrm{F}_{\text {hitung }} \leq \mathrm{F}_{\text {tabel }}$, maka $\mathrm{H}_{0}$ diterima

b. Jika $F_{\text {hitung }}>F_{\text {tabel }}$, maka $\mathrm{H}_{0}$ ditolak $\left(\mathrm{H}_{1}\right.$ diterima $)$

Hasil Perhitungan untuk uji $\mathrm{F}$ dapat dilihat pada Tabel berikut ini : 
Tabel 8. Hasil Perhitungan Uji F

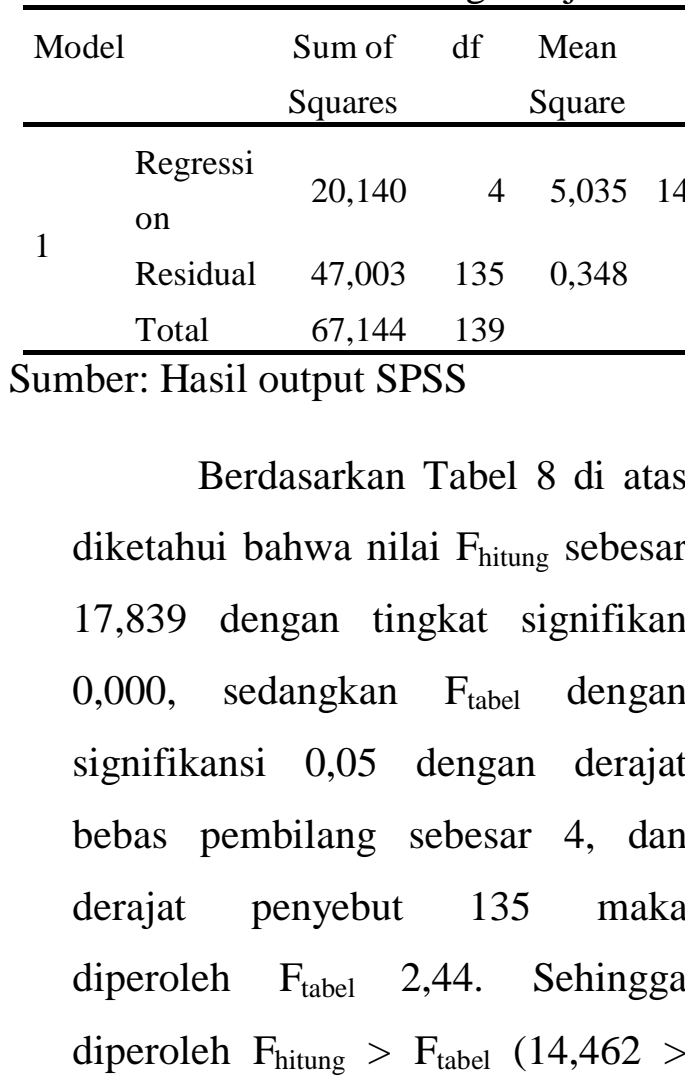

2,44) dan signifikan penelitian 0,000

$<0,05$, maka $\mathrm{H}_{0}$ ditolak dan $\mathrm{H}_{1}$ diterima. Dari hasil tersebut dapat disimpulkan bahwa profitabilitas yang diukur dengan return on assets, likuiditas yang diukur dengan current ratio dan pertumbuhan laba secara simultan berpengaruh terhadap kebijakan dividen.

\section{Uji Koefisien Determinasi $\left(\mathbf{R}^{2}\right)$}

Uji koefisien determinasi $\left(\mathrm{R}^{2}\right)$ dilakukan untuk menunjukkan seberapa besar hubungan antar variabel independen terhadap variabel dependen. Penentuan tersebut didasarkan pada kriteria Sig. yang menyebutkan jika hubungan mendekati 1, maka hubungan ,00@emakin kuat, sebaliknya jika hubungan mendekati 0, maka hubungan semakin lemah. Untuk melihat hasil uji koefisien determinasi dapat dilihat pada Tabel 4, diketahui bahwa nilai $\mathrm{R}$ Square $\left(\mathrm{R}^{2}\right)$ adalah sebesar 0,300. Hal ini berarti bahwa sebesar 30\% variabel dependen atau kebijakan dividen dipengaruhi oleh variabel independen yaitu ROA, CR, DER dan pertumbuhan laba. Sedangkan sisanya yaitu sebesar 70\% dijelaskan oleh faktor-faktor lain yang dapat mempengaruhi kebijakan dividen.

Dari hasil penelitian di atas, maka akan dibahas mengenai :

1. Pengaruh Profitabilitas (Return On Assets) terhadap Kebijakan Dividen

Hasil uji penelitian return on assets terhadap kebijakan dividen secara parsial berpengaruh positif dan signifikan terhadap kebijakan dividen. Maka hal ini menunjukkan bahwa semakin tinggi profitabilitas (return on assets) yang diperoleh suatu 
perusahaan semakin tinggi pula kebijakan dividen (dividend payout ratio) yang dibagikan. Profitabilitas menunjukan kemampuan perusahaan dalam memperoleh laba, sehingga dividen akan dibagikan apabila perusahaan memperoleh keuntungan yang layak untuk dibagikan oleh perusahaan kepada pemegang saham. Sekaligus menjadi suatu indikator bagi para calon investor dalam menanamkan modalnya terutama hasil dari dividen yang akan dibagikan oleh perusahaan. Pembayaran dividen dapat menunjukkan sinyal bahwa perusahaan memiliki prospek yang baik. Jika perusahaan mengumumkan peningkatan dividen, maka investor akan menganggap kondisi perusahaan saat ini dan akan datang relatif baik dan sebaliknya.. Hasil penelitian ini sesuai dengan penelitian terdahulu yang dilakukan oleh Nufiati dan Suwitho (2015), Pramana dan Sukarta (2015) dan Safrida (2014) yang menyatakan bahwa profitabilitas ( return on assets ) berpengaruh positif dan signifikan terhadap kebijakan dividen. sehingga hipotesis pertama $\left(\mathrm{H}_{1}\right)$ diterima bahwa profitabilitas (return on assets) berpengaruh signifikan terhadap kebijakan dividen.

2. Pengaruh Likuiditas (Current Ratio) terhadap Kebijakan Dividen

Hasil uji penelitian current ratio terhadap kebijakan dividen secara parsial berpengaruh negatif dan signifikan terhadap kebijakan dividen. Maka hal ini menunjukan bahwa semakin tinggi likuiditas akan menurunkan dividend payout ratio. Likuiditas menunjukkan kemampuan perusahaan dalam memenuhi kewajiban jangka pendeknya, hal ini menunjukkan apabila current ratio itu tinggi, yang berarti menunjukan bahwa kemampuan likuiditasnya tinggi, maka ada kecenderungan penggunaan modal kerja tidak optimal, sehingga akan menurunkan tingkat profitabilitas perusahaan, sehingga semakin tinggi tingkat likuiditasnya maka 
ada kecenderungan tingkat profitabilitas perusahaan rendah, dengan demikian dividen yang dibayarkan cenderung menurun. Penelitian ini sesuai dengan penelitian terdahulu yang dilakukan oleh Nufiati dan Suwitho (2015) yang menyatakan bahwa likuiditas (Current ratio) berpengaruh signifikan terhadap kebijakan dividen (dividend payout ratio) sehingga hipotesis kedua $\left(\mathrm{H}_{2}\right)$ diterima bahwa likuiditas (current ratio) berpengaruh signifikan terhadap kebijakan dividen.

3. Pengaruh Pertumbuhan Laba terhadap Kebijakan Dividen.

Hasil pengujian pertumbuhan laba terhadap kebijakan dividen secara parsial berpengaruh negatif dan signifikan. Maka semakin tinggi pertumbuhan laba yang diperoleh belum tentu perusahaan meningkatkan jumlah dividend payout ratio dan juga sebaliknya. hal ini mungkin disebabkan adanya rencana lain yang akan dilakukan oleh perusahaan, bagi perusahaan yang berkembang perusahaan cenderung akan menahan laba yang diperoleh untuk kepentingan perusahaan sehinggan pembayaran dividend payout ratio menurun. Penelitian ini tidak sejalan dengan penelitian terdahulu yang dilakukan oleh Rice dan Sulia (2014) yang menyatakan pertumbuhan laba tidak berpengaruh signifikan terhadap kebijakan dividen. Sehingga hipotesis ketiga $\left(\mathrm{H}_{3}\right)$ diterima bahwa pertumbuhan laba berpengaruh signifikan terhadap kebijakan dividen.

4. Pengaruh Leverage (Debt to Equity Ratio) terhadap Kebijakan Dividen.

Pengaruh debt to equity ratio terhadap kebijakan dividen secara parsial berpengaruh negatif dan signifikan. Maka jika debt to equity ratio meningkat akan diikuti dengan penurunan dividend payout ratio. Bahwa apabila utang meningkat akan memberikan pengaruh semakin rendahnya kemampuan perusahaan dalam membayar dividen. jika beban hutang 
perusahaan semakin besar maka dana yang dikeluarkan untuk membayar bunga pinjaman semakin besar sehingga mengurangi tingkat profitabilitas, maka hak para pemegang saham juga semakin berkurang. Penelitian ini sejalan dengan penelitian terdahulu yang dilakukan oleh Pramana dan Sukarta (2015) dan penelitian yang dilakukan oleh Agustini dan Fuadati (2017), namun tidak sejalan dengan penelitian yang dilakukan oleh Rice dan Sulia (2014) yang menyebutkan bahwa debt to equity ratio tidak berpengaruh signifikan terhadap kebijakan dividen. sehingga $\mathrm{H}_{4}$ diterima bahwa leverage (debt to equity ratio) berpengaruh signifikan terhadap kebijakan dividen.

\section{PENUTUP}

\subsection{Simpulan}

Tujuan dari penelitian ini adalah untuk menguji pengaruh dari profitabilitas dengan indikator return on assets, likuiditas dengan indikator current ratio dan pertumbuhan laba secara parsial terhadap penentuan kebijakan dividen pada perusahaan manufaktur yang terdaftar di Bursa Efek Indonesia periode 2012 - 2016 diperoleh hasil bahwa:

1. Variabel Profitabilitas (Return On Assets) berpengaruh signifikan terhadap kebijakan dividen pada perusahaan manufaktur yang terdaftar di BEI.

2. Variabel Likuiditas (Current Ratio) berpengaruh signifikan terhadap kebijakan dividen pada perusahaan manufaktur yang terdaftar di BEI.

3. Variabel Pertumbuhan Laba berpengaruh signifikan terhadap kebijakan dividen pada perusahaan manufaktur yang terdaftar di BEI.

4. Variabel Leverage (debt to equity ratio) berpengaruh signifikan terhadap kebijakan dividen pada perusahaan manufaktur yang terdaftar di BEI.

\subsection{Saran}

Berdasarkan hasil kesimpulan, maka peneliti memberikan beberapa saran, sebagai berikut: 
1. Investor sebaiknya membeli saham perusahaan yang memiliki tingkat profitabilitas yang baik sehingga investor memperoleh pembagian dividen yang tinggi.

2. Perusahaan yang digunakan sebagai sampel masih terbatas pada perusahaan manufaktur sehingga perlu dilakukan penelitian lebih lanjut dengan menggunakan sampel penelitian yang berbeda dalam waktu pengamatan yang lebih lama sehingga diharapkan hasil yang diperoleh dapat digeneralisasikan.

3. Melihat dari nilai adjusted $R$ square, hanya sebesar $30 \%$ saja variabel dependen dipengaruhi variabel-variabel independen dalam penelitian ini. Masih ada $70 \%$ variabel lain yang memengaruhi kebijakan dividen. Untuk itu penelitian selanjutnya disarankan untuk menambah variabel yang digunakan dalam penelitian.

\section{DAFTAR PUSTAKA}

Fahmi, Irham. 2014. Studi Kelayakan Bisnis. Mitra Wacana Media, Jakarta.
Ghozali, Imam. 2016. Aplikasi Analisis Multivariate dengan Program SPSS 23. Edisi 8. Badan Penerbit Universitas Diponegoro, Semarang.

Harjito, A. Dan Martono. 2014. Manajemen Keuangan. Edisi Kedua. Ekonisia. Yogyakarta.

Http://www.idx.co.id

Murhadi, W.R. 2015. Analisis Laporan Keuangan. Salemba Empat, Jakarta.

Nufiati dan Suwitho. 2015. Pengaruh Profitabilitas dan Likuiditas Terhadap Kebijakan Dividen Kas Pada Perusahaan Pefindo 25. Jurnal Ilmu dan Riset Manajemen. Volume 4 (3): 1-18.

Rachmawati dan Handayani. 2014. Pengaruh rasio keuangan dan kebijakan dividen terhadap pertumbuhan laba pada perusahaan manufaktur yang terdaftar di BEI. Jurnal Ilmu dan Riset Akuntansi Vol. 3 (3) : 1-15.

Sudana, I.M. 2015. Manajemen Keuangan Perusahaan. Erlangga, Jakarta.

Tampubolon, Manahan P. 2013. Managemen Keuangan. Mitra Wacana Media, Jakarta. 